\title{
A Social Network Perspective on Teacher Collaboration in Schools: Theory, Methodology, and Applications
}

\author{
NIENKE M. MOOLENAAR \\ University of Twente, The Netherlands, and University of California, San Diego
}

\begin{abstract}
An emerging trend in educational research is the use of social network theory and methodology to understand how teacher collaboration can support or constrain teaching, learning, and educational change. This article provides a critical synthesis of educational literature on school social networks among educators to advance our understanding of the embeddedness of teachers in the social context of schools. It focuses on how researchers currently use a social network perspective as a theoretical lens and methodology to frame studies on teacher collaboration in schools. Building on exemplary findings of recent studies, it shows that the pattern of social relationships among teachers may significantly enhance our understanding of the ways in which teacher collaboration takes place and contributes to student learning, teachers' instructional practice, and the implementation of reform. Finally, limitations and future directions in the conceptualization, measurement, and analysis of school social networks are indicated.
\end{abstract}

How central or peripheral are teachers' relations with colleagues to their success and satisfaction with students, their engagement in their present work, and their commitment to a career in teaching? What is the contribution that teachers' collegial involvement makes to the quality of the work force and the productivity of schools? (Judith Warren-Little 1990, 509)

In the past 20 years, educational researchers and policy makers have become increasingly interested in teacher relationships and teacher collaboration to support teacher professional development and capacity building in schools. In recognition of the dynamic role that teachers play in curriculum implementation and reform enactment, researchers and policy makers have begun to acknowledge the importance of teacher collaboration for strengthening

Electronically published September 24, 2012

American Journal of Education 119 (November 2012)

(C) 2012 by The University of Chicago. All rights reserved.

0195-6744/2012/11901-0002\$10.00 
schools and building individual teachers' knowledge. The questions posed above by Judith Warren-Little have sparked a tremendous body of research into the meaning and potential of teacher collaboration for issues such as student learning (Goddard et al. 2007; Louis and Marks 1998), teacher learning (Cochran-Smith and Lytle 1999; McLaughlin and Talbert 2006), and school improvement (Fullan 1992; Hargreaves 1991). Guided by this ongoing research and the intuitive appeal of the concept, educational practitioners and scholars around the world are targeting teacher collaboration to support teachers' professional development and enhance student achievement through a variety of collaborative initiatives, such as communities of practice and professional learning communities (Vescio et al. 2008; Wenger 1998).

A major challenge for research on teacher collaboration is that the concept has been interpreted in a very broad sense - for instance, as a form of school climate or culture encompassing norms of collegiality, trust, and social support; a management instrument to enhance school effectiveness; and a characteristic of a (professional learning) community (Mayrowetz 2008; Nias et al. 1989). This multifaceted interpretation of teacher collaboration has resulted in widespread and heterogeneous discourses on teacher collaboration, to the extent that "teacher collaboration has crystallized into multiple prisms, each of which contributes to a cliché ever present in any discourse about educational change, school effectiveness and improvement, school restructuring, and teacher professionalization" (Lavié 2006, 774).

Recently scholars have started to adopt a social network perspective to study teacher collaboration (e.g., Coburn and Russell 2008; Daly and Finnigan 2010, 2011; Daly, Moolenaar, Bolivar et al. 2010; Penuel et al. 2009). By examining social networks among teachers, these scholars attempt to capture teacher collaboration in a more straightforward way; namely, by focusing on the patterns of social relationships among teachers that result from their interactions in practice. The assumption underlying a social network perspective is that the patterns of social relationships among teachers (i.e., their social networks) offer a valuable framework for examining whether and to what degree teacher collaboration takes place.

Yet, what does it mean to take a social network perspective? What does this social network perspective have to offer to the study of teacher collaboration, how should its findings be interpreted, and what are potential draw-

Nienke M. MoOlenaAR is a postdoctoral researcher in the Department of Education Studies at the University of California, San Diego, and the Department of Educational Organisation and Management at the University of Twente, the Netherlands. Her research interests include social network analysis, social capital theory, school leadership, and organizational behavior. Direct correspondence to nmoolenaar@ucsd.edu.

\section{American Journal of Education}


backs of this perspective for studying teacher collaboration? Since the empirical base of social network studies in education is growing rapidly, there is an increasing need to reflect on the use of this social network perspective in educational research to advance our understanding of the embeddedness of teachers and their behavior in the social context of classrooms and schools (Warren-Little 2010). This article aims to do just that by answering the question, In what ways can a social network perspective contribute to research on teacher collaboration in support of teaching, learning, and educational change?

According to its advocates, a social network perspective may contribute to the understanding of teacher collaboration in at least two important ways (Coburn and Russell 2008; Daly 2010; Penuel et al. 2009). First, social network theory provides a powerful analytical framework and mechanisms that allow for a detailed investigation of the nature, antecedents, and outcomes of teacher collaboration. Using this framework, social network studies outside of education have indicated the significance of social networks for organizational performance and innovation (e.g., Nahapiet and Ghoshal 1998; Tsai and Ghoshal 1998) and suggested useful principles for the design of effective initiatives to enhance the value of collaboration (e.g., Cross et al. 2002).

Second, research on social networks builds on a long tradition of advanced and rigorous methodology and visualization to study relationships among individuals. Like most educational research, social network studies are multilevel by nature, meaning that these studies examine variables at different levels of analysis (e.g., teachers in schools) and thereby account for the nested structure of the data. In addition, social network studies include a level of analysis that is often overlooked - namely, the relational level (e.g., teachers in relationships; cf. Borgatti and Foster [2003]). By embedding teachers' individual behaviors in the pattern of their interpersonal relationships, social network analysis can capture the multilevel nature of teacher collaboration to an extent that conventional methods and measures cannot.

In this article, I explore these two ways in which a social network perspective may add to our understanding of teacher collaboration. To start, I explore how scholars currently use social network theory as a theoretical lens to frame studies on teacher collaboration. I continue by describing how recent educational studies use social network analysis as a method to visualize and evaluate the specific nature of teacher relationships in schools. To illustrate the use of a social network perspective in educational research, I provide an overview of studies that examine the significance of teachers' social networks for teaching, learning, and educational change. I draw from recent work that has been conducted in the United States, as well as from work on social networks in elementary school teams in the Netherlands. Finally, I discuss limitations and future directions that may further the use of a social network perspective in education. Acknowledging the importance of educators' social 
relationships and their effect on students, teachers, and schools has implications for educational research, practice, and policy. By providing an overview of the ways in which social network studies offer insights for educational research, this article aims to validate a social network perspective as a valuable addition to our current knowledge on teaching, learning, and educational change.

\section{Social Networks as a Theoretical Lens}

To argue why a social network perspective facilitates our understanding of human interaction, many scholars refer to social capital theory (Degenne and Forsé 1999; Portes 1998; Scott 2000). Social capital theory posits that social structure, or the web of relationships among individuals, offers opportunities and constraints for the exchange of resources. Individuals may tap into the resources that are available in the social structure in which they are embedded and leverage these resources to achieve individual or organizational goals (Nahapiet and Ghoshal 1998). While social capital theory offers a way to think about the potential of social structure for acquiring resources, social network theory seeks to reveal and understand certain patterns in this social structure and searches for tangible mechanisms that are responsible for its social capital outcomes (Burt 2000).

Social network theory has been driven by the desire to explain a wide range of real-world phenomena, such as social status and prestige (Lazega 2001); social influence and social selection (Frank and Fahrbach 1999; Marsden and Friedkin 1994); the spread and diffusion of innovation, diseases, and substance use (Hall and Valente 2007; Klovdahl 1985); and the small-world phenomenon also known as "six degrees of separation" (Watts 2001). In education, social network research can be used to shed light on concepts such as, among others, (distributed) leadership, professional learning communities, teacher collaboration, reform implementation, and teacher induction.

Social network research is characterized by three key assumptions about the embeddedness of individuals in social structure (Degenne and Forsé 1999). A social network perspective first assumes that resources, such as information and knowledge, are exchanged in the relationships among individuals. These resources flow through a social network and are transferred through social interaction among the individuals - for example, by asking for advice, collaborating, or helping (Borgatti and Ofem 2010; Burt 1992). In schools, for instance, teachers may exchange resources such as instructional materials and successful didactic strategies to overcome everyday classroom problems.

Second, social network theorists discard the idea that individuals are independent; rather, individuals are seen as interdependent because they are embedded in social structure (Degenne and Forsé 1999). The social embed- 
dedness of teachers in their school environment is visible at multiple levels; that is, teachers are embedded in dyadic (one-to-one) relationships, these dyadic relationships are set in larger subgroups such as grade-level teams and departments, and these groups eventually form larger social structures such as schools and districts. Because of this interpersonal interdependence at multiple levels, social network theorists argue that changes at a single level (e.g., teacher knowledge) will have consequences for a higher-order level (e.g., gradelevel expertise) and vice versa (Burt 2000).

Third, a social network perspective further implies that social networks may provide opportunities for, but also constrain, the actions of individuals and organizations. That is, in schools, teachers may benefit from the tangible and intangible resources that flow in a school's social network, such as instructional materials and expertise. Yet, teachers may only benefit from these resources if they have access to them through their social relationships. When the pattern of social relationships is such that many teachers are disconnected from the flow of resources in their school, that school's ability to achieve its goals may be hindered. Moreover, teachers can only benefit from the resources that are available in their school's network, and a lack of valuable resources or an abundance of less desired or undesired resources may also constrain a school's capacity for improvement.

\section{Social Networks in Education}

In recent years, educational studies have been building on social network theory to understand the complex role of teacher relationships in improving teaching and learning and in facilitating educational change. In general, a broad distinction can be made between two streams of social network research in education (Penuel, Frank et al. 2007).

The first stream of social network research in education examines teacher collaboration by analyzing networks across schools or districts (e.g., Lieberman 2000; Veugelers and Zijlstra 2002). Social network theory allows researchers to examine connections between individuals that may occur regardless of formal roles or institutional boundaries. This has led to network studies in education that examine networks that are not necessarily defined a priori, such as school-university partnerships in teacher training (e.g., Cornelissen et al. 2011); support networks of teachers both within and outside their school (e.g., Anderson 2010); and school partnerships in which two or more schools collaboratively work on a shared goal (e.g., Muijs et al. 2010). Such so-defined networks may consist of individuals from multiple schools who work collaboratively on a common purpose, like developing new curriculum implementation guidelines, co-constructing lesson strategies and rubrics, and imple- 
menting or evaluating school or district policy (e.g., Van Amersfoort et al. 2011). Studies examining these networks often use terms such as "networked learning" and "organizational learning" to examine the benefits of collaborative learning across multiple schools or districts as a strategy to meet increasing governmental pressure to improve overall performance (e.g., Ainscow 2010; Katz and Earl 2010).

The second stream of network research in education aims to understand teacher collaboration by analyzing social networks within schools or districts (e.g., Daly, Moolenaar, Bolivar et al. 2010; Moolenaar 2010; Moolenaar, Daly et al. 2011; Penuel et al. 2009). In spite of the potential of social network theory to examine teacher collaboration across a priori boundaries, most social network studies aim to understand phenomena that are situated in a particular group or bounded sample. Therefore, most networks that are examined within education are defined by formal or researcher-imposed boundaries - for instance, school or district networks. Networks in this sense can be regarded as patterns of relationships that reflect purposive interaction among educators in a bounded group, such as grade levels, subject matter departments, or schools. Studies interested in such networks often focus on how patterns of relationships among educators within schools or districts affect teachers' instructional practice, student learning, or the implementation of reforms. I focus this social network review on a bounded approach, since it is the most common one within educational research to date and reflects the focus of the articles in this special issue of the American Fournal of Education.

\section{Social Networks within Schools}

Research on within-school networks has yielded a number of fundamental findings on the pattern of teacher relationships within schools. From a review of social network studies in education, I identified at least five key findings on schools' network structure that appear to hold across studies.

Social network structure differs across schools. - There are considerable differences between schools with regard to their internal social network structure (Bakkenes et al. 1999; Daly, Moolenaar, Bolivar et al. 2010; Heyl 1996; Moolenaar 2010; Spillane and Healey 2010). For instance, in their qualitative study, Dorner et al. (2011) found notable differences between the schools under study in terms of the densities of networks and the likelihood of educators to engage in work-related advice and friendship relationships. Previous work with 53 Dutch elementary schools also suggested that there is variability between schools in the extent to which teachers interact with each other (Moolenaar 2010). On average, teachers were found to interact with about a third of their colleagues around work-related matters such as work discussions, collabora- 
tion, and advice (Moolenaar 2010; Moolenaar et al. 2012). Yet, the number of relationships varied from $10 \%$ in some schools to about $77 \%$ in others. ${ }^{1}$ In addition, networks may be more centralized around a few influential, informal leaders in some schools than in others. For instance, these same studies in Dutch schools found considerable variation in the extent to which principals occupy a central position in their school's advice network, resulting in differences in the influence they have on the system through direct advice relationships with teachers (Moolenaar, Daly et al. 2010). ${ }^{2}$

Schools' overall network structure is often fragmented, resulting in subgroups. - Teachers' relationships are often structured in subgroups within the overall pattern of teacher relationships in schools (Bidwell and Yasumoto 1999; Daly 2010; Penuel et al. 2009; Penuel, Frank et al. 2010; Zhao 2005). Social network theory offers two mechanisms that may explain why teachers cluster together in subgroups - namely, structural balance and homophily (Davis 1963; Heider 1958). Structural balance refers to the phenomenon that individuals are more likely to create new strong, direct ties with friends of friends and discontinue weaker relations with friends of enemies and enemies of friends, arguably in order to reduce psychological discomfort arising from cognitive dissonance. Because of this tendency toward the balance of strong, positive relationships, subgroups or cliques will emerge (Kossinets and Watts 2006). Subgroups may also emerge as a result of the principle of homophily, which asserts that individuals tend to form relationships based on how similar they are; for instance, with regard to age, gender, or educational level (Marsden 1988; McPherson et al. 2001). The more similar individuals are, the more quickly resources will flow among these individuals. The converse is also true in that dissimilar individuals are less likely to share resources. Research in schools indeed suggests that the principle of homophily may shape teacher networks into relatively homogenous subgroups based on similarities among educators, such as gender, ethnicity, discipline, and orientations toward teaching (Frank 1995, 1996; Heyl 1996; Penuel et al. 2009).

Schools' social network structure often deviates from formal hierarchical structure. - The formal structure of schools - that is, the way in which formal roles such as principal, coach, and teacher are organized - is often not fully aligned with the pattern of social relationships among educators in schools (Coburn 2005; Penuel, Frank et al. 2010; Spillane et al. 2010). Recent studies have indicated that educators in formal roles do not always enact their intended advisory roles as prominently as expected. For instance, in some schools coaches, subject area leaders, and administrators were found to play only a peripheral role in the advice networks of teachers, even though they were formally appointed to support teachers in making instructional changes (Atteberry and Bryk 2010; Coburn and Russell 2008; Cole and Weiss 2009; Kochan and Teddlie 2005; Penuel, Frank et al. 2010; Spillane and Healey 2010). 
Social networks serve multiple purposes and are shaped accordingly. - The content of social relationships matters for the ways in which social networks are structured. Teachers interact for different purposes in order to meet the intellectual, emotional, and social demands of teaching (Warren-Little 1990), and the resulting networks tend to overlap, as beneficial work relationships may develop into stronger personal relationships (Borgatti and Foster 2003; Casciaro and Lobo 2005). A common distinction based on the content of relationships is made between instrumental and expressive relationships (Ibarra 1993). Instrumental relationships refer to work-related relationships that are ultimately targeted at achieving school goals, such as the exchange of instructional materials or reform-related information. Expressive relationships refer to more affective-laden relationships that are not directly aimed at work-related issues and that often place the individual's interest above that of the organization, such as friendship and personal guidance (Burt 2005). In general, expressive ties are believed to be stronger, more durable, and trustworthy than instrumental relationships (Granovetter 1973; Marsden 1988).

Recent work on various types of educator networks indeed validates the difference between instrumental and expressive relationships (Finnigan and Daly 2010, 2012; Moolenaar et al. 2010, 2012). Moreover, teachers' workrelated interactions depend on the subject matter - for example, the exchange of advice around literacy versus mathematics (Spillane 2005) - and varies greatly in depth; for example, sharing materials versus having meaningful discussions about instructional issues (Coburn and Russell 2008). Yet, while research clearly suggests that networks differ according to their content and depth, it is unclear whether instrumental or expressive relationships are more prevalent among educators. Some studies showed that teachers are more densely connected through expressive ties than through instrumental ties (Cole and Weinbaum 2010; Dorner et al. 2011), while others suggest that teachers interact around work-related issues more than they engage in personal relationships (Daly, Moolenaar, Bolivar et al. 2010; Moolenaar and Sleegers 2010).

Social networks are shaped by various individual and school characteristics. - There are various characteristics of individuals and schools that appear to affect the social network structure in schools. The previous principle of homophily is well studied and explains how social networks are shaped by similarities among teachers. Findings show that teachers are more likely to interact with teachers who are similar to them with regard to gender, age, experience, ethnicity, grade level, subject matter, physical proximity, beliefs about teaching, and prior professional relationships (Bidwell and Yasumoto 1999; Coburn et al. 2010; Daly, Moolenaar, Bolivar et al. 2010; Gamoran et al. 2005; Heyl 1996; Kochan and Teddlie 2005; Moolenaar 2010; Penuel et al. 2009; Penuel, Riel et al. 2010; Spillane 2005; Yasumoto, Uekawa, and Bidwell 2001). Fewer studies have been conducted on how the social context of schools and social

\section{American Journal of Education}


issues pertaining to education - for example, ethnicity, teacher identity, teacher beliefs, local issues, and communication technologies - may shape teachers' tendencies to engage in social relationships.

A close examination of such school and teacher characteristics may signal opportunities for discovering underlying "rules of social engagement" that support or constrain teacher collaboration (Daly, Moolenaar, and Carrier 2010; Hill and Dunbar 2003). Findings in a sample of Dutch elementary schools indicate that teachers differ in their tendency to interact with each other, and this tendency is associated with demographic characteristics such as gender, age, experience, and grade level taught (Moolenaar 2010). For instance, female elementary school teachers are more likely to seek out others to discuss their work than male teachers do. Teachers in upper grade levels are also more likely to engage in work discussions compared to their colleagues in lower grades. Older and more experienced teachers are found to engage in work discussions to a lesser extent than their younger and less experienced colleagues. Moreover, the way in which a school is formally organized (gradelevel teams, cross-grade-level teams, interdependent teaching roles) and the amount of shared experience as a team affect the pattern of social relationships among educators (Moolenaar 2010; Penuel, Riel et al. 2010). Although preliminary, the discovery of such rules of social engagement may shape both effective and ineffective patterns of social exchange in schools and therefore warrant future research. In sum, these five findings offer a brief overview of current knowledge on the structure and properties of social networks in schools.

\section{Social Networks as a Method}

From the early beginning of social network research, studies have leaned heavily on particular methods (Freeman 2004). In this section, I provide a brief overview of social network analysis as a methodology to inform our thinking about teacher collaboration. I offer this overview in the form of a list of important methodological issues that researchers interested in social networks in education may want to consider when designing a network study.

\section{Whole School versus Ego Networks}

Social network research can examine various types of networks at different levels. Choosing and defining network boundaries is therefore an important decision in collecting social network data (Lima 2010). The most common approach in educational studies is to examine the whole network in a school. In this method, all educators in a bounded sample (e.g., a school or district) 
are asked to indicate with whom they interact in a certain manner, such as when asking for advice. Using this data, an advice network can be derived that reflects the pattern of advice relationships among educators in a school or district (e.g., Bidwell and Yasumoto 1999; Kochan and Teddlie 2005). Network studies may also focus on the networks of specific individuals, or socalled ego networks. In this method, focal individuals are selected at random or based on certain criteria, such as their formal position or membership on a particular team, and then often a snowball sampling technique (Patton 1990) is used to track down the people with whom they interact to shed light on the resource exchange between the focal actor and his or her personal network (e.g., Cornelissen et al. 2011).

The choice of which type of network to focus on depends on many factors: for example, the ability to define clear network boundaries, the level at which a researcher wishes to study a certain phenomenon (e.g., organizational-level phenomena require a whole-network approach, while individual-level and cross-organizational phenomena may be examined using an ego-network approach), and practical research constraints (e.g., in terms of time or access). If study questions do not necessarily warrant a whole network approach, the collection of ego-network data may have an advantage over a whole-network approach, because it does not require research participation by the majority of individuals in a network. A whole-network approach requires getting the commitment of one or more complete groups of respondents, as the typical response rate needs to exceed $80 \%$ in order to detect meaningful and reliable relational patterns from the data. In addition, a whole-network approach restricts the study's focus to relationships within formal or imposed boundaries, while educators' relational patterns that go beyond these borders may also contribute valuable resources to the organization. An implication of studying ego networks is that it may miss structural characteristics of the whole network that may offer additional explanations for the behavior or relational activity of individuals. Therefore, ego-network studies are often complemented by additional methods to uncover such additional explanations. In sum, there are many factors and implications that influence researchers' choice of network focus.

\section{Network Questions}

As previously described, social networks may differ according to the content of the resources that flow through the network. Network studies in education employ a wide variety of social network questions to capture these various networks. A few examples of social network questions from recent educational studies are presented in table 1 . These examples show that, when constructing 
TABLE 1

Examples of Social Network Questions from Recent Educational Studies

\begin{tabular}{|c|c|}
\hline Study/Content of Network & Survey Question \\
\hline \multicolumn{2}{|l|}{ Friedkin and Slater 1994: } \\
\hline Discussion & $\begin{array}{l}\text { In the column marked "Discuss," please } \\
\text { check the name of any person in the } \\
\text { school with whom you discuss events } \\
\text { or issues which arise in the school }\end{array}$ \\
\hline Advice & $\begin{array}{l}\text { In the column marked "Advice," please } \\
\text { check the name of any person in the } \\
\text { school to whom you turn for advice } \\
\text { in events or issues which arise in the } \\
\text { school }\end{array}$ \\
\hline Friendship & $\begin{array}{l}\text { In the column marked "Friend," please } \\
\text { check the name of any person in the } \\
\text { school whom you consider to be a } \\
\text { close personal friend }\end{array}$ \\
\hline
\end{tabular}

Kochan and Teddlie 2005:

Working with

Please list the three persons you would most prefer to work with during the spring semester or on a task force that has been created to study ways of improving the educational environment at this school

Serving on a committee

Please list the three individuals with whom you would most like to serve during the spring semester on a committee that has been created to tackle student disciplinary problems at this school

Sharing an office

In answering the following question, assume that your school has office spaces for all teachers. Please select the three individuals with whom you would feel most comfortable sharing an office space during the coming academic year

Nomination

Please select the three persons whom you would like to choose to represent you during the coming year on a committee created to improve faculty welfare

Informal association

Please list the three persons with whom you most prefer to associate in an informal social setting (occasion) after school hours 


\begin{tabular}{|c|c|}
\hline Study/Content of Network & Survey Question \\
\hline \multicolumn{2}{|l|}{ Cole and Weiss 2009: } \\
\hline Classroom management & $\begin{array}{l}\text { To whom, in your school, have you } \\
\text { turned to for advice about classroom } \\
\text { management during this school year? }\end{array}$ \\
\hline $\begin{array}{l}\text { Course content and } \\
\text { planning }\end{array}$ & $\begin{array}{l}\text { During this school year, to whom in } \\
\text { your school have you gone for help } \\
\text { in selecting and planning course con- } \\
\text { tent coverage and pacing? }\end{array}$ \\
\hline $\begin{array}{l}\text { Low-performing } \\
\text { students }\end{array}$ & $\begin{array}{l}\text { During this school year, to whom in } \\
\text { your school have you turned for ad- } \\
\text { vice on strategies to assist low per- } \\
\text { forming students? }\end{array}$ \\
\hline Reform & $\begin{array}{l}\text { Please list the people inside or outside } \\
\text { your school to whom you turned for } \\
\text { advice in using [reform name] during } \\
\text { this school year }\end{array}$ \\
\hline Friendship & $\begin{array}{l}\text { During this school year, with whom } \\
\text { among your colleagues at this school } \\
\text { do you "hang out" and discuss family, } \\
\text { home, and/or personal issues? }\end{array}$ \\
\hline \multicolumn{2}{|l|}{ Pitts and Spillane 2009: } \\
\hline $\begin{array}{l}\text { Advice seeking on } \\
\text { teaching }\end{array}$ & $\begin{array}{l}\text { To whom have you turned for advice or } \\
\text { information about teaching in general? }\end{array}$ \\
\hline $\begin{array}{l}\text { Advice seeking on } \\
\text { mathematics }\end{array}$ & $\begin{array}{l}\text { To whom have you turned for advice or } \\
\text { information about math teaching strat- } \\
\text { egies and content? }\end{array}$ \\
\hline $\begin{array}{l}\text { Advice seeking on } \\
\text { literacy }\end{array}$ & $\begin{array}{l}\text { To whom have you turned for advice or } \\
\text { information about literacy teaching } \\
\text { strategies and content? }\end{array}$ \\
\hline \multicolumn{2}{|l|}{ Daly and Finnigan 2010: } \\
\hline Knowledge & $\begin{array}{l}\text { Please select the administrators [in the } \\
\text { district] to whom you go to for } \\
\text { knowledge related to the [literacy] re- } \\
\text { form effort . . . and at what fre- } \\
\text { quency? }\end{array}$ \\
\hline Advice & $\begin{array}{l}\text { Please select the administrators [in the } \\
\text { district] to whom you go to for ad- } \\
\text { vice related to implementation of the } \\
\text { [literacy] reform effort ... . and at } \\
\text { what frequency? }\end{array}$ \\
\hline Innovation & $\begin{array}{l}\text { Please select the administrators [in the } \\
\text { district] to whom you turn to for in- } \\
\text { novative practice related to the [liter- } \\
\text { acy] reform effort . . . and at what } \\
\text { frequency? }\end{array}$ \\
\hline
\end{tabular}


a social network questionnaire, researchers have to make decisions on design factors regarding the format of the question, the format of the answer, and the collection of additional information that may be required to delineate the social network structure (see table 2). Finally, researchers should carefully determine the order in which social network questions are being posed, as a recent study found question-order effects in teacher social network surveys (Pustejovsky and Spillane 2009). For instance, respondents' answers on social network surveys may, after a few items, become biased as a result of fatigue (social network surveys tend to be longer than regular surveys), cognitive priming (naming a few colleagues with whom one collaborates may steer a respondent's answers to subsequent questions), or other reasons (see Pustejovsky and Spillane 2009).

\section{Network Measures}

In addition to visualizing social network data in sociograms, social network studies often calculate network measures from information gathered through social network interviews or surveys. While there are many measures that can be chosen to reflect a wide variety of network characteristics, below I briefly describe those that are commonly used to delineate teachers' social networks.

As an indicator of an individual's social network, educational researchers often focus on the centrality of educators in their social network, assessed as the total or average number of relationships they maintain (e.g., Baker-Doyle and Yoon 2011; Dorner et al. 2011) or the percentage of relationships in relation to the total number of relationships in the network (e.g., Friedkin and Slater 1994; Moolenaar, Daly et al. 2011). The more central an educator is in a school's network, the more opportunities he or she has to access resources, information, or support from the social network (Balkundi and Kilduff 2005; Krackhardt 1996), as well as to guide, control, and even broker the flow of information and resources (Burt 2005). Figure 1 displays an example of a teacher network in a Dutch elementary school, representing advice relationships for actively engaging students. In this network, the coach (represented by a triangle) occupies a very central position, as many teachers ask her for advice. In contrast, the principal is not asked for this type of advice and seeks advice for herself around this topic from two teachers and the coach. Another individual network characteristic is ego-reciprocity, which reflects the two-way nature of the relationships. A relationship between two educators is reciprocal when both respondents indicate having a relationship with one another. In figure 1, the coach has low ego-reciprocity, as she is asked for advice by many teachers but does not have a mutual advice relationship with any of these teachers. In addition, individual network characteristics can be derived by 
TABLE 2

Design Factors in the Construction of Social Network Surveys

\begin{tabular}{|c|c|}
\hline Type of Question & Question \\
\hline \multicolumn{2}{|l|}{ Format of the question: } \\
\hline Content & $\begin{array}{l}\text { Which type of interaction does the } \\
\text { study aim to address (e.g., advice, } \\
\text { friendship)? }\end{array}$ \\
\hline Subject matter & $\begin{array}{l}\text { Is the question posed to elicit subject- } \\
\text { specific or general forms of interac- } \\
\text { tion (e.g., advice about mathematics } \\
\text { instruction vs. advice about instruc- } \\
\text { tion)? }\end{array}$ \\
\hline Sample & $\begin{array}{l}\text { Does the question guide the respondents } \\
\text { to a bounded or open sample (e.g., } \\
\text { please name any person in your } \\
\text { school vs. please name any person)? }\end{array}$ \\
\hline Nature of relationship & $\begin{array}{l}\text { Will the question direct respondents to } \\
\text { only choose colleagues with whom } \\
\text { they like or prefer to interact or whom } \\
\text { they are closest to, or will the ques- } \\
\text { tion be posed in general terms (e.g., } \\
\text { who do you like to interact with most } \\
\text { vs. who do you interact with)? }\end{array}$ \\
\hline $\begin{array}{l}\text { Fixed vs. open time } \\
\text { frame }\end{array}$ & $\begin{array}{l}\text { Will the question refer to a specific time } \\
\text { period in which interactions could } \\
\text { have occurred (e.g., during the past } 2 \\
\text { weeks, over the past year)? }\end{array}$ \\
\hline
\end{tabular}

Format of the answer:

Free recall vs. recognition

Is the respondent asked to freely recall any interactions with colleagues, or is $\mathrm{s} /$ he offered a fixed list of potential colleagues with whom interaction could take place?

Open vs. fixed number of relationships

Can a respondent name as many colleagues as s/he wants, or is this number fixed?

Additional information on relationships:

Name generator vs. name interpreter

Frequency

Is the respondent asked to only generate the names of colleagues with whom s/he interacts or also to provide information on these colleagues (e.g., kinship, formal position, previous professional relationships)?

Is the respondent asked to indicate how often interactions take place (e.g., almost daily, less than once a month)? 
TABLE 2 (Continued)

\begin{tabular}{lc}
\hline Type of Question & Question \\
\hline Value of relationship & Is the respondent asked to value the in- \\
& dicated relationships in any way (e.g., \\
& through ranking or indicating how \\
important the relationship is)? & Is the respondent asked to provide rea- \\
sons for interacting with these col- \\
leagues and not others?
\end{tabular}

combining several network and individual characteristics into a new composite measure. For instance, Frank et al. (2004) calculated a teacher's access to expertise by multiplying the frequency of interaction with the expertise of the person with whom he or she interacted (see also Bidwell and Yasumoto 1999; Frank et al. 2010; Pil and Leana 2009).

At the school level, educational researchers are often interested in measures that reflect the cohesion, reciprocity, and centralization of the social network as a whole, as well as the extent to which the network is fragmented into subgroups. The network measure of density can be used to indicate group cohesion (Blau 1977). The overall reciprocity in a network reflects the extent to which relationships in a network are mutual. In figure 1, the overall reciprocity of the advice network is rather low, with few teachers being engaged in mutual relationships. It is plausible that advice-seeking relationships are low on reciprocity because of the asymmetrical nature of this relationship, while other relationships such as friendship and social support have a higher tendency to be reciprocated. Centralization represents the variability in the centrality of individuals in a network. A network with high centralization is characterized by one or a few highly central educator(s) and many other more peripheral educators (see Wasserman and Faust 1998). The extent to which a network is characterized by subgroups - for instance, formed around certain individual characteristics or aligned with formal boundaries like grade levels - can be assessed using a clustering algorithm developed by Frank (1995). ${ }^{3}$

\section{Missing Data and Respondent Inaccuracy.}

While researchers typically work to avoid missing data and use a sample that is as representative as possible, collecting a complete data set is of even greater importance when conducting social network research (Lima 2010; Wasserman and Faust 1998). High response rates are essential for valid and reliable network analyses, because data from the individual about others and data from 


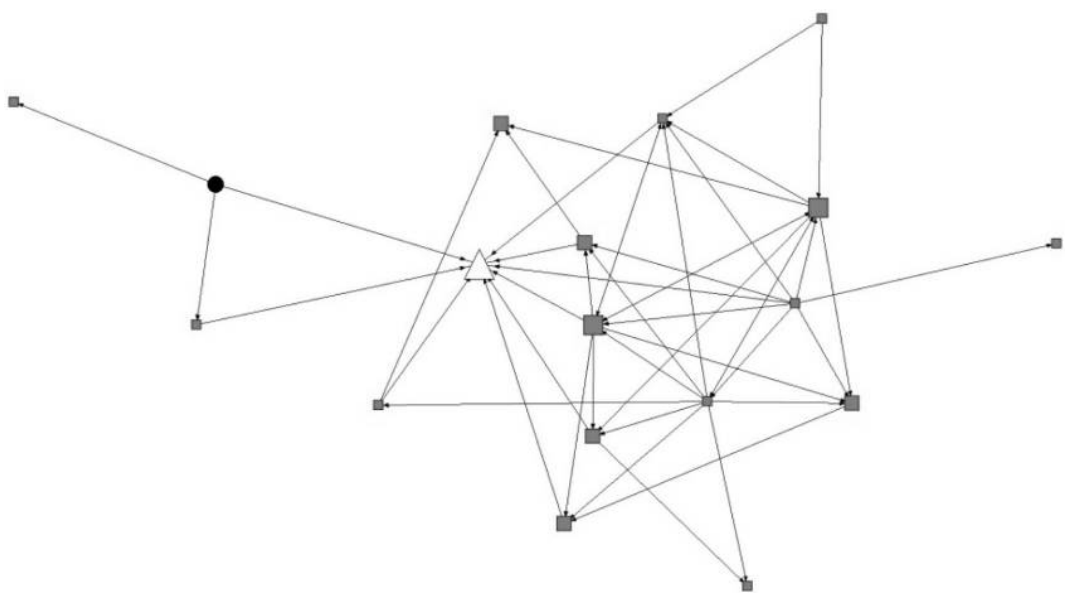

Fig. 1.-Example of a school social network in a Dutch school representing advice relationships to actively engage students. NOTE: Teachers are represented by squares, the principal is represented by the circle in the left corner, and the coach is represented by the triangle. Arrowed lines represent advice-seeking relationships.

others about the individual are needed to understand dyadic relationships and their patterns in networks. Therefore, network researchers should carefully attend to issues such as the definition of network boundaries and nonresponse. ${ }^{4}$ Moreover, in designing surveys or interviews, attention should be given to the careful formulation of network questions to limit respondent inaccuracy due to misinterpretation (e.g., Lima 2010).

\section{Software and Advanced Modeling to Assess Social Networks}

The popularization of the study of social networks in various research fields such as sociology, organizational science, psychology, and education is supported by the emergence and development of more sophisticated and widely accessible statistical tools for social network analysis (e.g., Monge and Contractor 2003). In education, such models could provide valuable insights into how patterns of social relationships among teachers may change during and after the implementation of reforms and how this network change is related to school improvement. Currently, to our knowledge, only a few network studies in education capitalize on the vast potential offered by these advanced statistical models (e.g., Daly, Moolenaar, and Carrier 2010; Penuel, Riel et al. 2010). 
Social Networks for Teaching, Learning, and Educational Change

Educational studies that employ a social network perspective build on one or more main premises regarding network influence on school outcomes. The ultimate argument for examining social networks among teachers is the premise that patterns of teacher relationships affect student achievement. Moreover, a school's social network structure is argued to achieve this impact through its potential to affect teachers' instructional practices. By far the largest group of social network studies in education examines the premise that a school's social network structure supports or constrains the implementation of reform and, as such, mediates efforts at school improvement. In the next section I present evidence for each of these premises, reflecting on recent studies on teachers' social networks in schools.

\section{Social Networks and Student Learning}

An important assumption underlying most research into teacher collaboration is that teachers' relationships ultimately influence student learning (Chrispeels et al. 2007; Wood 2007). While empirical studies suggest that a broad interpretation of teacher collaboration may increase student achievement (Lomos et al. 2011; Vescio et al. 2008), there are few studies that examine the link between student achievement and actual patterns of teacher relationships. Yet, a close examination of teachers' social networks may uncover the extent to which teachers have access to resources, knowledge, and new information that helps them overcome obstacles of daily practice and facilitates the achievement of instructional goals.

Findings of the few recent studies into this relationship seem to support the notion that teachers' individual access to resources through their relationships affects student performance (Leana and Pil 2006; Pil and Leana 2009; Yasumoto et al. 2001). For instance, in a large-scale study of 199 elementary schools, Pil and Leana (2009) found that the strength of relationships that teachers maintained with their colleagues positively predicted student performance. Furthermore, teacher relationships were found to moderate the impact of teacher ability on student performance. Recent work also indicates that the extent to which teachers share knowledge around reading comprehension is positively related to both summative and formative assessments of students' reading levels and that this relationship may be mediated by individual teachers' experience (Daly et al. 2011, forthcoming). While these studies underline the importance of individual teachers' access to knowledge for student performance through their network, recent evidence also suggests that the density and centralization of schools' overall network structure may not be directly 
linked to overall school performance (Moolenaar, Sleegers et al. 2011; Pil and Leana 2009). Rather, these measures potentially indirectly affect student achievement through various school- and teacher-level variables, such as collective responsibility, collective efficacy, trust among principals and teachers, and teacher influence on decision making (Goddard et al. 2007; Moolenaar et al. 2009; Moolenaar and Sleegers 2010; Moolenaar, Sleegers et al. 2011; Penuel, Frank et al. 2010; Spillane et al. 2010; Yasumoto et al. 2001).

In sum, recent studies lend support for the premise that teachers' individual network positions impact student performance and that the overall pattern of teacher relationships in schools offers the potential for creating a work environment that indirectly benefits student achievement.

\section{Social Networks and Teaching}

Teachers' instructional practice is an important link through which resources that teachers access through their social networks, such as new knowledge and curricular materials, may permeate their classrooms. The literature mentions at least three ways in which the pattern of teacher relationships within schools may affect teachers' instructional practice - by offering opportunities to learn; shaping processes of social influence and social selection; and creating a safe, supportive environment for learning (see Chapman and Aspin 2003).

Evidently, teacher interactions in social networks provide opportunities for teachers to learn from each other. Social network literature suggests that interactions within subgroups may offer learning opportunities that are different from interactions that take place between subgroups and that both types of interaction are important (Anderson 2010; Burt 2005). More specifically, interaction within subgroups may reinforce constructive school norms of formal support, mutual help, and shared responsibility for student achievement that shape an environment conducive to achieving instructional goals (Bidwell and Yasumoto 1999; Penuel et al. 2006; Penuel, Frank et al. 2010; Penuel, Riel et al. 2010; Spillane et al. 2010), while interaction between subgroups may benefit teachers in terms of access to novel resources and information diversity (Burt 1992).

Another way in which social interactions affect teachers' instructional practice is by shaping a process of social influence (Frank and Fahrbach 1999; Marsden and Friedkin 1994). Studies have indicated that within subgroups, teachers influence each other to the extent that they share common pedagogical beliefs, attitudes, and ideas about teaching practices (Gamoran et al. 2005; Penuel, Frank et al. 2010). In addition, direct and indirect connections between teachers are found to affect their attitudes toward reform (Bidwell and Yasumoto 1999; Cole and Weinbaum 2010). The extent to which teachers

\section{American Journal of Education}


reach out to others and their grounds for choosing these others is referred to as a process of social selection (Frank and Fahrbach 1999). For this process of social selection to benefit teachers and schools, it is imperative that teachers know where to find the expertise in their school team (Coburn et al. 2010; Cross et al. 2002). Yet, research suggests that teachers are often unaware of each other's expertise and experience, and schools fail to capitalize on the expertise of teachers who are isolated from the knowledge exchange in their schools (Baker-Doyle and Yoon 2010, 2011; Bakkenes et al. 1999).

Finally, there is abundant research suggesting that social relationships may influence teachers' practice by creating a safe environment in which teachers can engage in innovative practices and experiment with new instructional strategies without the fear of being punished or ridiculed (Bryk and Schneider 2002; Daly, Moolenaar, Bolivar et al. 2010; Moolenaar, Daly et al. 2011; Penuel, Fishman et al. 2007). Indeed, schools with dense social network structures have been characterized by higher levels of trust among teachers, an open orientation toward new practices and change, and shared perceptions of the school's ability to achieve collective goals (Moolenaar et al. 2009, 2010; Moolenaar, Daly et al. 2011). In turn, such characteristics were found to lead teachers to make changes in their classroom practice (Penuel, Frank et al. 2010).

To summarize, recent research appears to support the notion that the pattern of teacher relationships shapes conditions needed to change teachers' practice by providing learning opportunities, supporting processes of social selection and social influence, and nurturing an open and safe climate in which school-wide capacity for teacher development is advanced.

\section{Social Networks to Support Educational Change}

Social networks and relationships are inextricably connected to educational change (Chapman and Aspin 2003; Fullan 2001; Warren-Little 2010). All around the world, school districts are developing and implementing various school improvement policies to respond to increased accountability demands and sanctions for underperformance (Daly, 2009; Mintrop and Trujillo 2007). As educational change has proven an especially challenging task, particularly in top-down efforts (Fullan 2001), our understanding of policy implementation may be enhanced by examining efforts at implementation "from the inside out" (Goldspink 2007, 45). Patterns of teacher relationships and collaboration offer a valuable starting point to enhance our understanding of the success and failure of school reform initiatives. Therefore, many recent social network studies in education aim at exploring how social network patterns affect the implementation of reform. In turn, research suggest that the "shock" of a new reform initiative may cause the dynamics of teacher interaction to change in 
order to accommodate the demands of the reform; this creates a feedback loop in which reform demands and teacher interactions continuously influence each other (see Cole and Weinbaum 2010; Darling-Hammond and McLaughlin 1995). In the next section, I provide an overview of insights into the interplay between teachers' social network structure and reform in support of educational change.

\section{Patterns of Teacher Relationships Shape Efforts at Reform Implementation}

As many scholars have argued, instructional change can only be built upon a foundation of teacher knowledge (Hargreaves 2003; Lieberman 2000). Social network scholars add that the success of reform initiatives is not just dependent on the level of individual teachers' knowledge but also on the extent to which the social structure in schools allows for knowledge to be exchanged, shared, discussed, and adapted (Coburn and Russell 2008; Daly, Moolenaar, Bolivar et al. 2010). Frequent social interactions among educators are believed to facilitate the implementation of reform, since frequent knowledge exchange allows for mutual sense making, co-construction, collective learning, adaptation of reform to specific classroom situations, and shared understanding of reform goals (Coburn 2005; Daly 2010; Datnow et al. 2006; Grossman et al. 2000).

Several scholars argue that the pattern of teacher relationships at the onset of reform implementation is crucial to its success (Camburn et al. 2003; Coburn 2005), since these relationships allow for reform to become embedded in the routines, actions, and behavior of educators (Chapman and Aspin 2003). Indeed, patterns of teachers' social relationships have been associated with schools' capacity to change (Penuel, Frank et al. 2007, 2010). Recent case studies indicate that network characteristics of schools may explain why some schools succeed in implementing reforms and others fail (Penuel et al. 2009; Penuel, Frank et al. 2007). For instance, frequent teacher interaction increases the likelihood that teachers are willing to embrace new innovations (Moolenaar et al. 2010) such as the use of computers in the classroom (Frank et al. 2004). In addition, the depth and spread of reform implementations are influenced by various characteristics of teacher relationships in schools, such as the overall horizontal pattern of relationships among teachers, the amount of vertical relationships between teachers and so-called reform experts (e.g., principals, coaches, and educators with experience in implementing reforms), and crosssubgroup relationships that allow teachers to come in contact with diverse information and opinions about the reform (Atteberry and Bryk 2010; Daly, Moolenaar, Bolivar et al. 2010; Penuel et al. 2009; Penuel, Frank et al. 2010; Penuel, Riel et al. 2010). These findings underline that the implementation 
of reforms in schools is not only dependent on the reform's technical and curricular aspects (to which current policy instruments are so often directed); it is also a function of the social environment in schools (Daly and Finnigan, forthcoming; Spillane et al. 2006).

\section{Policy Decisions and Reform Design Affect the Pattern of Teacher Relationships}

While patterns of relationships shape efforts at reform implementation, scholars also claim the inverse - namely, that policy decisions and characteristics of large-scale implementation programs affect the dynamics of interpersonal relationships among educators (e.g., Coburn and Russell 2008). Efforts at educational change are likely to spark a host of new interactions around the proposed change at least because many reform efforts are nowadays supported by collaborative initiatives and new formal structures (e.g., coaching and mentoring) that require mutual adaptation and communication (e.g., DarlingHammond and McLaughlin 1995). Several studies have indicated that the implementation of reforms placing a special focus on collaboration increases the extent to which teachers identify and interact with people possessing expertise on the reform (Atteberry and Bryk 2010; Baker-Doyle and Yoon 2010; Coburn et al. 2010). Along the same lines, Coburn and Russell (2008) found that a reform initiative that included the appointment of mathematics coaches increased the span and strength of relationships in schools, as well as teachers' access to expertise around the reform. Yet, the nature and quality of these relationships were mediated by the conditions of the policy and the design of the initiative, as well as school leaders' decisions on the way in which coaches were used. These findings suggest that while the structure of teachers' social networks at the onset of reform may be crucial to its success, policy provisions and decisions regarding reform may also change the dynamic of social relationships in schools.

As the structure of social networks at the outset of a reform affects the success of the reform's implementation, and reform efforts themselves may change existing patterns of social relationships, the interaction between social network change and educational change often creates a continuous loop of mutual influence that deserves further attention (Atteberry and Bryk 2010; Chapman and Aspin 2003). Sufficient time is an essential factor in both the success of reform efforts as well as the development of strong, supportive social networks (Amersfoort et al. 2011; Moolenaar 2010). When reform efforts are continuously built upon nonsupportive social structures and there is not enough time to adapt the social structure to accommodate the demands of the reform, these efforts have limited chance of being implemented as intended, and schools may wind up in a revolving door of reform efforts (Daly, 
Moolenaar, and Carrier 2010). A close examination of the conditions under which reform efforts can succeed and be sustained is, therefore, as vital as the development and evaluation of specific reform efforts themselves. Further studies employing a social network perspective may prove valuable in evaluating both the former and latter aims.

\section{Limitations and Future Directions}

Since its origin in the 1920s, scholars have been debating whether the field of social network research has its own distinctive theory and, as such, is more than just a research tool (Granovetter 1979; Wasserman and Faust 1998). By mapping the current terrain, I have shown that studies of social networks within schools offer valuable conceptual and methodological contributions to our understanding of the patterns of social relationships that underlie teacher collaboration in schools. Yet, while premises on the significance of social network structure for teaching, learning, and educational change seem to hold up under empirical scrutiny, there are many gaps in our knowledge that call for further research before substantive conclusions can be made about the robustness and significance of these premises for educational practice.

\section{Multiple Levels of Analysis}

Although network studies are multilevel by nature, existing studies seldom simultaneously examine networks at multiple levels of analysis; for instance, by taking into account individual network characteristics of teachers (e.g., centrality), dyadic characteristics of their relationships (e.g., homophily), and organizational network characteristics of schools (e.g., density) in the prediction of student achievement. Such an approach is challenging due to the interrelatedness of network measures (e.g., individual-level centrality and schoollevel centralization) but nonetheless extremely valuable, because network measures may have different conceptual meanings and consequences at different levels of analysis. For example, at the individual level, a principal occupying a central position may have an advantage in influencing the exchange of information while, at the team level, a highly centralized team may face an organizational disadvantage due to the low distribution of resources among its members (Moolenaar et al. 2010). 


\section{Moolenaar}

\section{Generalizability and Causality}

Another limitation in current social network research is the small number of studies directly connecting teachers' social interactions to student achievement, with the majority of these studies focusing on elementary education in the United States. As such, the generalizability of these studies could be expanded by examining this relationship on a larger scale in various international educational settings. Moreover, many social network studies either rely on crosssectional data or represent small-scale case studies, using a wide range of surveys and interviews to delineate social networks and thereby limiting the possibility to draw overarching conclusions about the significance of social networks. Furthermore, as is apparent from the review of recent social network studies, social relationships are often interpreted simultaneously as cause and effect. Thus, in future empirical studies, more attention should be given to issues of generalizability and causality - for instance, by exploring social networks with integral models and studying social relationships over time using a network methodology that facilitates comparisons among multiple studies.

\section{Need for Integral Models}

A further limitation apparent from this literature synthesis is the scarcity of empirical evidence on mediating variables that help to explain the relationship between social networks and school outcomes. While most studies until now have focused on the nature, the antecedents, or the consequences of social networks for schools, there is a pressing need for integral models that examine the chain of variables linking teachers' social relationships to student achievement (Moolenaar 2010). Educational practice may benefit from studies that, in one comprehensive model, examine the characteristics that shape networks through mechanisms such as homophily and structural balance-for example, individual teachers' demographical data, teacher beliefs, or intentions; the resulting network properties themselves - individual network position, subgroup clustering, or network density; and the effect these network patterns have on educational outcomes - teacher instructional practices or the implementation of reform. Such studies may provide valuable insights into which types of social interactions create optimal teacher learning opportunities, how teacher learning takes place in these interactions, and how and when this learning becomes apparent in teachers' daily practice and, ultimately, student achievement. Undertaking these types of studies are challenging, as they imply a complex framework in which many variables interact with each other in a dynamic empirical setting (Daly et al. 2011; De Laat et al. 2007). Yet, the 
history of leadership literature (e.g., Yukl 1981) teaches us that the call for integral frameworks often arises when an idea is gaining momentum. Considering the dramatic increase in social network studies over the past decade, scholars will justifiably voice the need for such integral models more often, and with more emphasis.

\section{Studying Social Interactions over Time}

Social networks are dynamic and change over time (Kilduff and Tsai 2003). As is apparent from social network studies in education, it is imperative to understand how patterns of social relationships both shape, and are shaped by, social contexts in schools. Particularly powerful in this regard are recent qualitative studies that unearth the social complexity and power plays that occur in social networks as they change over time (e.g., Anderson 2010; BakerDoyle 2011; Daly and Finnigan 2011).

A promising lens on the interplay between individual behavior and social structure that has remained largely empirically untouched is Burt's (1982) structural theory of action. He argues that individuals act to achieve goals in line with their personal interests and that both their interests and the resulting actions are constrained by the existing social structure and the larger environment. By adding a temporal dimension, Leydesdorff (1991) highlights the circular character of this theory, illustrating that social structure is both an antecedent and a consequence of individual social action. Other promising theoretical lenses that may enhance our understanding of the interplay of antecedents and consequences of networks over time are complexity theory (Daly, Moolenaar, and Carrier 2010) and utility-based theory (Frank et al. 2010). Such theories may frame and enhance our thinking on how teacher collaboration is embedded in, and interacts with, both individual teacher behavior and the larger school environment and may offer useful indications for targeting and optimizing teacher collaboration in support of increased school performance.

\section{The Dark Side of Social Networks}

Since social networks are often examined for the positive outcomes for individuals, organizations, and communities, it is important to note that the social structures in which resources are exchanged may also take unfavorable forms. These forms contradict a normative standpoint from which social networks are interpreted as an "unmixed blessing" (Portes 1998). Besides the appealing benefits of strong bonding among educators, potential downsides 
may include the exclusion of outsiders, free riding within groups, strong social control resulting in restrictions on individual freedom, and downward leveling norms that socialize group members into accepting lower standards (Field 2003). In the current discourse, such phenomena and their implications for practice have been largely overlooked and deserve future attention for their potential to disrupt the flow of resources and constrain efforts at school improvement (Lima 2010).

\section{Networked Interventions}

What also is missing in the current discourse is knowledge on how supportive conditions for strong networks may be fostered through designed interventions, such as professional learning communities, critical friends groups, and coaching. Such interventions can focus on helping teachers know how to localize and access expertise in their school (Penuel and Riel 2007). As a prerequisite, teachers should know or learn how to reflect on their own expertise and teaching needs, since this will help them to "open up to research and other people's ideas" (Lieberman 2011, 2). In addition, it should be noted that optimizing the pattern of social relationships among educators does not necessarily imply the creation of more relationships but, rather, a more strategic attempt to optimize social networks to reflect a balanced pattern of strong and weak, direct and indirect, and deep and superficial relationships (Anderson 2010; Baker-Doyle 2011; Penuel et al. 2009). According to Cross and colleagues (2002), networks will be more efficient and effective in exchanging resources when four conditions are met: (1) network members are aware of each other's expertise, (2) network members have sufficient access to this expertise, (3) network exchange occurs in a safe environment, and (4) network members are actively committed to the exchange of resources. Designing and evaluating interventions based on these conditions may support educational practitioners in capitalizing on the potential of the social networks for the improvement of practice.

\section{Conclusion}

The potential of a social network perspective for understanding teacher collaboration has been recognized by a growing number of educational studies. A review of the current social network studies in education shows that relationships matter. For scholars, the value of examining these relationships with a social network perspective can be found in its considerable theoretical base as well as its rigorous methodology, which provides the ability to visualize and 
analyze teacher interactions and make teacher collaboration more tangible than ever before (Moolenaar 2010; Muijs et al. 2010). For educational practice, insights into social networks may help shape and enhance collaborative initiatives that capitalize on teacher relationships for teaching, learning, and educational change.

A social network perspective may provide valuable answers to the opening questions posed by Warren-Little some 20 years ago (Warren-Little 1990). Yet, while we can conclude that teachers' relations with colleagues are central to issues of student learning, teaching, and educational change, what is also apparent is that there is much more work to do. As the exploration of teachers' social networks has already shown promising findings for school improvement, scholars and practitioners are advised to capitalize on the advantages of the social network perspective by examining its theoretical premises in practice, applying its rigorous methodologies, designing and evaluating interventions to identify and localize untapped expertise, and exploring teacher collaboration in a way that conventional perspectives and methods have not. In doing so, a social network perspective can and will yield insights that advance and in some cases even alter our thinking on teaching, learning, and educational change.

\section{Notes}

This work was supported by the Netherlands Organisation for Scientific Research (NWO) under the research program Rubicon (grant 446-10-023).

1. The average density of the work discussion network was $36.9 \%$ (SD $=11.9 \%$, Min $=14.7 \%$, Max $=76.7 \%)$. The average density of the collaboration network was $36.4 \%(\mathrm{SD}=14.9 \%$, Min $=13.1 \%$, Max $=74.4 \%)$. The average density of the advice network was $26.9 \%(\mathrm{SD}=11.1 \%$, Min $=9.8 \%$, Max $=53.5 \%)$.

2. On average, we found the degree of principal centrality to vary between 0.03 and 0.89 , with 0.00 meaning that a principal is not asked for advice at all and 1.00 reflecting a principal's position in which all teachers search only the principal for advice, with no other central actors in the network $(M=.35, \mathrm{SD}=.18, \mathcal{N}=51$ schools; Moolenaar et al. 2010).

3. Additional information on how to collect and analyze social network data can be found in Borgatti et al. (1998); Lima (2010); Marsden (1988); and Pitts and Spillane (2009).

4. See Lima (2010) for useful strategies on how to deal with missing data.

5. Common software programs to analyze social network data are UCINET (Borgatti et al. 2002) and R packages for network analysis, such as SIENA (Ripley et al. 2011). A recent upsurge in the availability of advanced statistical methods to study social networks has expanded and advanced the field tremendously. A particularly interesting recent development is the introduction of $p 2$ and $p^{*}$ exponential random graph models (ERGM), which provide opportunities to study the influence of covariates, such as demographics or behavior, on the probability of ties to gain insights into network change over time (Robins et al. 2007). For an overview of most available network 


\section{Moolenaar}

software, see http://www.insna.org/software/index.html; for SIENA, see http://www .stats.ox.ac.uk/ snijders/siena/; and for R, see http://erzuli.ss.uci.edu/R.stuff/.

\section{References}

Ainscow, Mel. 2010. "Achieving Excellence and Equity: Reflections on the Development of Practices in One Local District over 10 Years." School Effectiveness and School Improvement 21 (1): 75-92.

Amersfoort, D. L. van, M. Korenhof, N. M. Moolenaar, and M. F. de Laat. 2011. "Exploring New Horizons: Teacher Professional Development through Networked Learning." Paper presented at the European Association for Research on Learning and Instruction, Exeter.

Anderson, Lauren. 2010. "Embedded, Emboldened, and (Net)Working for Change: Support-Seeking and Teacher Agency in Urban, High-Needs Schools." Harvard Education Review 80 (4): 541-72.

Atteberry, Allison, and Anthony S. Bryk. 2010. "Centrality, Connection, and Commitment: The Role of Social Networks in a School-Based Literacy Initiative." In Social Network Theory and Educational Change, ed. A. J. Daly. Cambridge, MA: Harvard University Press.

Baker-Doyle, Kira J. 2011. The Networked Teacher. New York: Teachers College Press.

Baker-Doyle, Kira J., and Susan A. Yoon. 2010. "Making Expertise Transparent: Using Technology to Strengthen Social Networks in Teacher Professional Development." In Social Network Theory and Educational Change, ed. A. J. Daly. Cambridge, MA: Harvard University Press.

Baker-Doyle, Kira J., and Susan A. Yoon. 2011. "In Search of Practitioner-Based Social Capital: A Social Network Analysis Tool for Understanding and Facilitating Teacher Collaboration in a US-Based STEM Professional Development Program." Professional Development in Education 37 (1): 75-93.

$\rightarrow$ Bakkenes, I., C. De Brabander, and J. Imants. 1999. "Teacher Isolation and Communication Network Analysis in Primary Schools." Educational Administration Quarterly 35 (2): 166-202.

$\rightarrow$ Balkundi, P., and M. Kilduff. 2005. "The Ties That Lead: A Social Network Approach to Leadership." Leadership Quarterly 16 (6): 941-61.

$\rightarrow$ Bidwell, Charles E., and Jeffrey Y. Yasumoto. 1999. "The Collegial Focus: Teaching Fields, Collegial Relationships, and Instructional Practice in American High Schools." Sociology of Education 72 (4): 234-56.

Blau, P. M. 1977. Inequality and Heterogeneity. New York: Free Press.

Borgatti, Stephen P., Martin G. Everett, and Linton C. Freeman. 2002. UCINET for Windowes: Software for Social Network Analysis. Cambridge, MA: Analytic Technologies.

Borgatti, Stephen P., and P. Foster. 2003. "The Network Paradigm in Organizational Research: A Review and Typology." Journal of Management 29 (6): 991-1013.

Borgatti, Stephen P., Candace Jones, and Martin G. Everett. 1998. "Network Measures of Social Capital." Connections 21 (2): 27-36.

Borgatti, Stephen P., and Brandon Ofem. 2010. "Overview: Social Network Theory and Analysis." In Social Network Theory and Educational Change, ed. A. J. Daly. Cambridge, MA: Harvard University Press.

Bryk, A. S., and B. Schneider. 2002. Trust in Schools: A Core Resource for School Improvement. New York: Russell Sage Foundation.

Burt, R. S. 1982. Toward a Structural Theory of Action. New York: Academic Press. 
Burt, R. S. 1992. Structural Holes. Cambridge, MA: Harvard University Press.

$\rightarrow$ Burt, R. S. 2000. "The Network Structure of Social Capital." Research in Organizational Behavior 22:345-423.

Burt, R. S. 2005. Brokerage and Closure: An Introduction to Social Capital. Oxford: Oxford University Press.

$\rightarrow$ Camburn, E., B. Rowan, and J. E. Taylor. 2003. "Distributed Leadership in Schools: The Case of Elementary Schools Adopting Comprehensive School Reform Models." Educational Evaluation and Policy Analysis 25:347-73.

Casciaro, T., and M. S. Lobo. 2005. "Competent Jerks, Lovable Fools and the Formation of Social Networks." Harvard Business Review 83 (June): 92-99.

Chapman, J. D., and D. N. Aspin. 2003. "Networks: A New Construct for Educational Provision and a New Strategy for Reform." In Handbook of Educational Leadership and Management, ed. B. Davies and J. West-Burnham. London: Pearson.

Chrispeels, J. H., G. Andrews, and M. Gonzalez. 2007. "System Supports for Teacher Learning and School Improvements." In International Handbook of School Effectiveness and Improvement, ed. T. Townsend. Dordrecht: Springer.

$\rightarrow$ Coburn, Cynthia E. 2005. "Shaping Teacher Sensemaking: School Leaders and the Enactment of Reading Policy." Educational Policy 19 (3): 476-509.

Coburn, Cynthia E., Linda Choi, and Willow Mata. 2010. "I Would Go to Her Because Her Mind Is Math: Network Formation in the Context of a District-Based Mathematics Reform." In Social Network Theory and Educational Change, ed. A. J. Daly. Cambridge, MA: Harvard University Press.

$\rightarrow$ Coburn, Cynthia E., and Jennifer Lin Russell. 2008. "District Policy and Teachers' Social Networks." Education Evaluation and Policy Analysis 30 (3): 203-35.

Cochran-Smith, M., and S. Lytle. 1999. "Teacher Learning Communities." Review of Research in Education 24:24-32.

Cole, Russell P., and Elliot H. Weinbaum. 2010. "Changes in Attitude: Peer Influence in High School Reform." In Social Network Theory and Educational Change, ed. A. J. Daly. Cambridge, MA: Harvard University Press.

Cole, Russell, and Michael Weiss. 2009. "Identifying Organizational Influentials: Methods and Application Using Social Network Data." Connections 29 (2): 45-61.

$\rightarrow$ Cornelissen, Frank, Jacqueline van Swet, Douwe Beijaard, and Theo Bergen. 2011. "Aspects of School-University Research Networks That Play a Role in Developing, Sharing and Using Knowledge Based on Teacher Research." Teaching and Teacher Education 27 (1): 147-56.

$\rightarrow$ Cross, R., A. Parker, and S. P. Borgatti. 2002. "Making Invisible Work Visible: Using Social Network Analysis to Support Strategic Collaboration." California Management Review 44 (2): 25-46.

$\rightarrow$ Daly, Alan J. 2009. "Rigid Response in an Age of Accountability." Educational Administration Quarterly 45 (2): 168-216.

Daly, Alan J. 2010. Social Network Theory and Educational Change. Cambridge, MA: Harvard University Press.

$\rightarrow$ Daly, Alan J., and Kara Finnigan. 2010. "Understanding Network Structure to Understand Change Strategy." Journal of Educational Change 11 (2): 111-38.

$\rightarrow$ Daly, Alan J., and Kara S. Finnigan. 2011. "The Ebb and Flow of Social Network Ties between District Leaders under High-Stakes Accountability." American Educational Research Fournal 48 (1): 39-79.

Daly, Alan J., and Kara S. Finnigan. Forthcoming. "Exploring the Space Between: Social Networks, Trust, and Urban School District Leaders." Journal of School Leadership.

$\rightarrow$ Daly, Alan J., Nienke M. Moolenaar, Jose M. Bolivar, and Peggy Burke. 2010. "Re-

34 American Journal of Education 


\section{Moolenaar}

lationships in Reform: The Role of Teachers' Social Networks." Fournal of Educational Administration 48 (3): 359-91.

Daly, Alan J., Nienke M. Moolenaar, and N. Carrier. 2010. "Reform at the Edge of Chaos: Connecting Complexity, Social Networks, and Policy Implementation." Paper presented at the annual meeting of the American Educational Research Association, Denver.

Daly, Alan J., Nienke M. Moolenaar, Claudia Der-Martirosian, and Janet Chrispeels. 2011. "A Capital Investment: The Effects of Teacher Human and Social Capital on Student Achievement in Improving Schools." Paper presented at the TwentyFourth Annual International Congress for Effective Schools, Cyprus.

Daly, Alan J., Nienke M. Moolenaar, Claudia Der-Martirosian, and Y-H. Liou. 2012. "Tied to Reading: Investigating the Effects of Social Networks on Formative Student Achievement." Unpublished manuscript, University of California, San Diego.

$\rightarrow$ Darling-Hammond, Linda, and M. W. McLaughlin. 1995. "Policies That Support Professional Development in an Era of Reform." Phi Delta Kappan 76 (8): 597-604.

Datnow, A., S. Lasky, S. Stringfield, and C. Teddlie. 2006. Systemic Integration for Effective Reform in Racially and Linguistically Diverse Contexts. Cambridge: Cambridge University Press.

$\rightarrow$ Davis, J. A. 1963. "Structural Balance, Mechanical Solidarity, and Interpersonal Relations." American Fournal of Sociology 68:444-62.

Degenne, Alain, and Michel Forsé. 1999. Introducing Social Networks. London: Sage.

$\rightarrow$ De Laat, M. F., V. Lally, L. Lipponen, and P. R. J. Simons. 2007. "Patterns of Interaction in a Networked Learning Community: Squaring the Circle." International Fournal of Computer-Supported Collaborative Learning 2:87-103.

$\rightarrow$ Dorner, Lisa M., James P. Spillane, and James Pustejovsky. 2011. "Organizing for Instruction: A Comparative Study of Public, Charter, and Catholic Schools." Fournal of Educational Change 12:71-98.

Field, J. 2003. Social Capital. New York: Routledge.

Finnigan, Kara S., and Alan J. Daly. 2010. "Learning at a System Level: Ties between Principals of Low-Performing Schools and Central Office Leaders." In Social Network Theory and Educational Change, ed. A. J. Daly. Cambridge, MA: Harvard University Press.

$\rightarrow$ Finnigan, Kara S., and Alan J. Daly. 2012. "Mind the Gap: Organizational Learning and Improvement in an Underperforming Urban System." American Fournal of Education 119 (1): 41-71.

$\rightarrow$ Frank, Kenneth A. 1995. "Identifying Cohesive Subgroups." Social Networks 17:27-56.

$\rightarrow$ Frank, Kenneth A. 1996. "Mapping Interactions within and between Cohesive Subgroups." Social Networks 18:93-119.

$\rightarrow$ Frank, Kenneth A., and Kyle Fahrbach. 1999. "Organization Culture as a Complex System: Balance and Information in Models of Influence and Selection." Organization Science 10:253-77.

Frank, Kenneth A., Chong Min Kim, and Dale Belman. 2010. "Utility Theory, Social Networks, and Teacher Decision-Making: Modeling Networks' Influences on Teacher Attitudes and Practices." In Social Network Theory and Educational Change, ed. A. J. Daly. Cambridge, MA: Harvard University Press.

$\rightarrow$ Frank, Kenneth A., Y. Zhao, and K. Borman. 2004. "Social Capital and the Diffusion of Innovations within Organizations: Application to the Implementation of Computer Technology in Schools." Sociology of Education 772:148-71.

Freeman, Linton G. 2004. The Development of Social Network Analysis: A Study into the Sociology of Science. Vancouver: Empirical Press. 
$\rightarrow$ Friedkin, N. E., and M. Slater. 1994. "School Leadership and Performance: A Social Network Approach." Sociology of Education 67:139-57.

Fullan, Michael G. 1992. Successful School Improvement: The Implementation Perspective and Beyond: Modern Educational Thought. Milton Keynes: Open University Press.

Fullan, Michael. 2001. Leading in a Culture of Change. San Francisco: Jossey-Bass.

Gamoran, A., R. Gunter, and T. Williams. 2005. "Professional Community by Design: Building Social Capital through Teacher Professional Development." In The Social Organization of Schooling, ed. Larry V. Hedges and Barbara Schneider. New York: Russell Sage Foundation.

Goddard, Y. L., R. D. Goddard, and M. Tschannen-Moran. 2007. "A Theoretical and Empirical Investigation of Teacher Collaboration for School Improvement and Student Achievement in Public Elementary Schools." Teachers College Record 109 (4): 877-96.

$\rightarrow$ Goldspink, Chris. 2007. "Rethinking Educational Reform: A Loosely Coupled and Complex Systems Perspective." Educational Management Administration and Leadership 35 (1): 27-50.

$\rightarrow$ Granovetter, Mark S. 1973. "The Strength of Weak Ties." American Fournal of Sociology 78 (1): 1360-80.

Granovetter, Mark S. 1979. "The Theory Gap in Social Network Analysis." In Perspectives on Social Network Research, ed. P. W. Holland and S. Leinhardt. New York: Academic Press.

Grossman, Pamela, S. S. Wineburg, and S. Woolworth. 2000. What Makes Teacher Community Different from a Gathering of Teachers? Seattle: Center for the Study of Teaching and Policy, University of Washington.

$\rightarrow$ Hall, Jeffrey A., and Thomas W. Valente. 2007. "Adolescent Smoking Networks: The Effects of Influence and Selection on Future Smoking." Addictive Behaviors 32 (12): 3054-59.

Hargreaves, Andrew. 1991. "Contrived Collegiality: The Micropolitics of Teacher Collaboration." In The Politics of Life in Schools: Power, Conflict, and Cooperation, ed. Joseph Blase. Newbury Park, CA: Sage.

Hargreaves, D. H. 2003. Education Epidemic: Transforming Secondary Schools through Innovation Networks. London: Demos.

Heider, Fritz. 1958. The Psychology of Interpersonal Relations. New York: Wiley.

Heyl, Erwin. 1996. "Het Docentennetwerk: Structuur en Invloed van Collegiale Contacten binnen Scholen." PhD diss., University of Twente.

$\rightarrow$ Hill, R. A., and R. I. M. Dunbar. 2003. "Social Network Size in Humans." Human Nature 14:53-72.

$\rightarrow$ Ibarra, Herminia. 1993. "Personal Networks of Women and Minorities in Management: A Conceptual Framework." Academy of Management Review 18 (1): 56-87.

$\rightarrow$ Katz, Steven, and Lorna Earl. 2010. "Learning about Networked Learning Communities." School Effectiveness and School Improvement 21 (1): 27-51.

Kilduff, Martin, and Wenpin Tsai. 2003. Social Networks and Organizations. London: Sage.

$\rightarrow$ Klovdahl, A. S. 1985. "Social Networks and the Spread of Infectious Diseases: The AIDS Example." Social Science and Medicine 21 (11): 1203-16.

$\rightarrow$ Kochan, Susan, and Charles Teddlie. 2005. "An Evaluation of Communication among High School Faculty Using Network Analysis," in "Social Network Analysis in Program Evaluation," ed. M. Durland and K. Fredericks, special issue, Nerw Directions for Evaluation 107 (Fall): 41-53.

$\rightarrow$ Kossinets, G., and D. J. Watts. 2006. "Empirical Analysis of an Evolving Social Network." Science 311:88-90. 


\section{Moolenaar}

Krackhardt, D. 1996. "Social Networks and the Liability of Newness for Managers." Fournal of Organizational Behavior 3:159-73.

$\rightarrow$ Lavié, J. M. 2006. "Academic Discourses on School-Based Teacher Collaboration: Revisiting the Arguments." Educational Administration Quarterly 42 (5): 773-805.

Lazega, E. 2001. The Collegial Phenomenon: The Social Mechanisms of Cooperation among Peers in a Corporate Law Partnership. Oxford: Oxford University Press.

$\rightarrow$ Leana, C., and F. Pil. 2006. "Social Capital and Organizational Performance: Evidence from Urban Public Schools." Organization Science 17 (3): 353-66.

$\rightarrow$ Leydesdorff, L. 1991. "The Static and Dynamic Analysis of Network Data Using Information Theory." Social Networks 13 (4): 301-45.

$\rightarrow$ Lieberman, Ann. 2000. "Networks as Learning Communities: Shaping the Future of Teacher Development." Fournal of Teacher Education 51:221-27.

Lieberman, Ann. 2011. "Q\&A with Ann Lieberman." AERA Educational Change Special Interest Group: Lead the Change Series 2 (July): 1-3.

Lima, Jorge A. 2010. "Studies of Networks in Education: Methods for Collecting and Managing High-Quality Data." In Social Network Theory and Educational Change, ed. A. J. Daly. Cambridge, MA: Harvard University Press.

$\rightarrow$ Lomos, Catalina, Roelande H. Hofman, and Roel J. Bosker. 2011. "Professional Communities and Student Achievement: A Meta-Analysis." School Effectiveness and School Improvement 22 (2): 121-48.

$\rightarrow$ Louis, K. S., and H. M. Marks. 1998. "Does Professional Community Affect the Classroom? Teachers' Work and Student Experiences in Restructuring Schools." American Fournal of Education 106 (4): 532-75.

$\rightarrow$ Marsden, Peter V. 1988. "Homogeneity in Confiding Relations." Social Networks 10: $57-76$.

$\rightarrow$ Marsden, Peter V., and Noah E. Friedkin. 1994. "Network Studies of Social Influence." Sociological Methods and Research 22 (1): 127-51.

$\rightarrow$ Mayrowetz, David. 2008. "Making Sense of Distributed Leadership: Exploring the Multiple Usages of the Concept in the Field." Educational Administration Quarterly 44: 424-35.

McLaughlin, M. W., and J. E. Talbert. 2006. Building School-Based Teacher Learning Communities: Professional Strategies to Improve Student Achievement. New York: Teachers College Press.

$\rightarrow$ McPherson, J. M., L. Smith-Lovin, and J. M. Cook. 2001. "Birds of a Feather: Homophily in Social Networks." Annual Review of Sociology 27:415-44.

$\rightarrow$ Mintrop, H., and T. Trujillo. 2007. "The Practical Relevance of Accountability Systems for School Improvement: A Descriptive Analysis of California Schools." Educational Evaluation and Policy Analysis 29 (4): 319-52.

Monge, P. R., and N. S. Contractor. 2003. Theories of Communication Networks. New York: Oxford University Press.

Moolenaar, Nienke M. 2010. "Ties with Potential: Nature, Antecedents, and Consequences of Social Networks in School Teams." PhD diss., University of Amsterdam.

$\rightarrow$ Moolenaar, Nienke M., Alan J. Daly, and Peter J. C. Sleegers. 2010. "Occupying the Principal Position: Examining Relationships between Transformational Leadership, Social Network Position, and Schools' Innovative Climate." Educational Administration Quarterly 46:623-70.

Moolenaar, Nienke M., Alan J. Daly, and Peter J.C. Sleegers. 2011. "Ties with Potential: Social Network Structure and Innovative Climate in Dutch Schools." Teachers College Record 113 (9): 1983-2017.

Moolenaar, Nienke M., S. Karsten, Peter J. C. Sleegers, and B. J. H. Zijlstra. 2009. "Professional School Communities from a Social Capital Perspective: An Empirical 
Study across Multiple Levels of Analysis." Paper presented at the annual meeting of the American Educational Research Association, San Diego, CA.

Moolenaar, Nienke M., and Peter J. C. Sleegers. 2010. "Social Networks, Trust, and Innovation: How Social Relationships Support Trust and Innovative Climates in Dutch Schools." In Social Network Theory and Educational Change, ed. Alan J. Daly. Cambridge, MA: Harvard University Press.

$\rightarrow$ Moolenaar, Nienke M., Peter J. C. Sleegers, and Alan J. Daly. 2011. "Teaming Up: Linking Collaboration Networks, Collective Efficacy, and Student Achievement." Teaching and Teacher Education 28 (2): 251-62.

Moolenaar, Nienke M., Peter J. C. Sleegers, Sjoerd Karsten, and Alan J. Daly. 2012. "The Social Fabric of Elementary Schools: A Network Typology of Social Interaction among Teachers." Educational Studies, 1-17. DOI: 10.1080/03055698.2011 .643101 .

$\rightarrow$ Muijs, Daniel, Mel West, and Mel Ainscow. 2010. "Why Network? Theoretical Perspectives on Networking." School Effectiveness and School Improvement 21 (1): 5-26.

$\rightarrow$ Nahapiet, J., and S. Ghoshal. 1998. "Social Capital, Intellectual Capital, and the Organizational Advantage." Academy of Management Review 23 (2): 242-66.

Nias, J., G. Southworth, and A. Yeomans. 1989. Staff Relationships in the Primary School. London: Cassells.

Patton, M. Q. 1990. Qualitative Evaluation and Research Methods. Newbury Park, CA: Sage.

$\rightarrow$ Penuel, William R., B. J. Fishman, R. Yamaguchi, and L. P. Gallagher. 2007. "What Makes Professional Development Effective? Strategies That Foster Curriculum Implementation." American Educational Research Fournal 44 (4): 921-58.

Penuel, William R., Kenneth A. Frank, and Ann Krause. 2006. "The Distribution of Resources and Expertise and the Implementation of Schoolwide Reform Initiatives." In Proceedings of the 7th International Conference of the Learning Sciences, ed. Sasha A. Barab et al. Mahwah, NJ: Erlbaum.

Penuel, William R., Kenneth A. Frank, and Ann Krause. 2010. "Between Leaders and Teachers: Using Social Network Analysis to Examine the Effects of Distributed Leadership." In Social Network Theory and Educational Change, ed. Alan J. Daly. Cambridge, MA: Harvard University Press.

Penuel, William R., Kenneth A. Frank, and Willow Sussex. 2007. Research Exchange on Teacher Networks: Report from a Workshop. Menlo Park, CA: SRI International.

$\rightarrow$ Penuel, William R., and M. R. Riel. 2007. "The 'New' Science of Networks and the Challenge of School Change." Phi Delta Kappan 88 (8): 611-15.

$\rightarrow$ Penuel, William R., M. Riel, A. Joshi, L. Pearlman, C. M. Kim, and K. A. Frank. 2010. "The Alignment of the Informal and Formal Organizational Supports for Reform: Implications for Improving Teaching in Schools." Educational Administration Quarterly 46 (1): 57-95.

Penuel, William R., Margaret Riel, Ann E. Krause, and Kenneth A. Frank. 2009. "Analyzing Teachers' Professional Interactions in a School as Social Capital: A Social Network Approach." Teachers College Record 111 (1): 124-63.

$\rightarrow$ Pil, F., and C. Leana. 2009. "Applying Organization Research to Public School Reform." Academy of Management Fournal 56 (2): 1101-24.

$\rightarrow$ Pitts, V. M., and J. P. Spillane. 2009. "Using Social Network Methods to Study School Leadership." International Fournal of Research and Method in Education 32 (2): 185-207.

$\rightarrow$ Portes, A. 1998. "Social Capital: Its Origins and Applications in Modern Sociology." Annual Review of Sociology 24:1-24.

$\rightarrow$ Pustejovsky, J. E., and J. P. Spillane. 2009. "Question-Order Effects in Social Network Name Generators." Social Networks 31:221-29. 
Ripley, Ruth M., Tom A. B. Snijders, and P. P. Lopez. 2011. "Manual for RSIENA." Department of Statistics, University of Oxford, Oxford.

$\rightarrow$ Robins, G., T. A. B. Snijders, P. Wang, M. S. Handcock, and P. Pattison. 2007. "Recent Developments in Exponential Random Graph $\left(p^{*}\right)$ Models for Social Networks." Social Networks 29 (2): 192-215.

Scott, J. 2000. Social Network Analysis. London: Sage.

$\rightarrow$ Spillane, James P. 2005. "Primary School Leadership Practice: How the Subject Matters." School Leadership and Management 25 (4): 383-97.

$\rightarrow$ Spillane, James P., and Kaleen Healey. 2010. "Conceptualizing School Leadership and Management from a Distributed Perspective: An Exploration of Some Study Operations and Measures." Elementary School Fournal 11 (2): 253-81.

Spillane, James P., Kaleen Healey, and Chong Min Kim. 2010. "Leading and Managing Instruction: Formal and Informal Aspects of the Elementary School Organization." In Social Network Theory and Educational Change, ed. A. J. Daly. Cambridge, MA: Harvard University Press.

Spillane, James P., B. J. Reiser, and L. M. Gomez. 2006. "Policy Implementation and Cognition: The Role of Human, Social, and Distributed Cognition in Framing Policy Implementation." In New Directions in Education Policy Implementation: Confronting Complexity, ed. M. Honig. Albany: State University of New York Press.

$\rightarrow$ Tsai, W., and S. Ghoshal. 1998. "Social Capital and Value Creation: The Role of Intrafirm Networks." Academy of Management Fournal 41 (4): 464-78.

$\rightarrow$ Vescio, V., D. Ross, and A. Adams. 2008. "A Review of Research on the Impact of Professional Learning Communities on Teaching Practice and Student Learning." Teaching and Teacher Education 24 (1): 80-91.

$\rightarrow$ Veugelers, W., and H. Zijlstra. 2002. "What Goes on in a Network? Some Dutch Experiences." International Fournal of Leadership in Education 5 (2): 163-74.

Warren-Little, Judith. 1990. "The Persistence of Privacy: Autonomy and Initiative in Teachers' Professional Relations." Teachers College Record 91 (4): 509-36.

Warren-Little, Judith. 2010. "Foreword." In Social Network Theory and Educational Change, ed. A. J. Daly. Cambridge, MA: Harvard University Press.

Wasserman, Stanley, and Katherine Faust. 1998. Social Network Analysis. Cambridge: Cambridge University Press.

Watts, D. 2001. Six Degrees: The Science of a Connected Age. New York: Norton.

Wenger, E. 1998. Communities of Practice: Learning, Meaning, and Identity. New York: Cambridge University Press.

Wood, D. R. 2007. "Teachers' Learning Communities: Catalyst for Change or a New Infrastructure for the Status Quo?" Teachers College Record 109 (3): 699-739.

$\rightarrow$ Yasumoto, J. Y., K. Uekawa, and C. Bidwell. 2001. "The Collegial Focus and Student Achievement: Consequences of High School Faculty Social Organization for Students on Achievement in Mathematics and Science." Sociology of Education 74:181209.

Yukl, G. 1981. Leadership in Organizations. Englewood Cliffs, NJ: Prentice-Hall.

Zhao, Y. 2005. "Subgroups as a Meso-Level Entity in the Social Organization of Schools." In The Social Organization of Schooling, ed. Larry V. Hedges and Barbara Schneider. New York: Russell Sage Foundation. 